\title{
Colin Crouch: The Strange Non-Death of Neoliberalism
}

Cambridge: Polity Press 2011, pp. 224

Since the outbreak of the financial and banking crisis - with the subprime crisis in the US in the Spring of 2007 - there has been no lack of attempts at explanation accompanied by a swan song to the era of neoliberalism and the doctrine of unrestricted markets. But in spite of the state's massive interventions to support the financial market and individual, so-called system-relevant financial service providers, power relations have neither shifted for the benefit of the state, nor has the prevailing doctrine of the market as an instrument of allocation been significantly weakened. It is unsurprising that in view of the extent of the transnational crisis, the state, or more precisely the states, appear to be more reluctant than proactive actors. Democracy and intergovernmental coordination processes require more time than buying decisions on computer-based markets. However, if the market failure - of the financial sector, what is in theory the most efficient of all markets - cannot be mastered without major state intervention and if the representatives of neoliberalism call for the help of the state as a matter of course - whereby, according to the prevailing doctrine, this market intervention can only cause inefficiency - then this should be conducive to a mind shift in the economy and a focus on alternatives in politics.

There have been alternatives. Colin Crouch reminds his readers - the book addresses social scientists who do not necessarily have an economic background as well as politically interested laymen - of alternative positions: ordoliberalism of the Freiburg School and social market economy, left-wing liberalism with its North American character, Keynesianism and corporatism from the 1970s. But most notably he explains the rise of neoliberalism from the practical failure of "social democratic" economic orders of the post-war period in the wake of the oil crisis and the threat of recession and unemployment or inflation associated with it. Even if some aspects of this outline turn out rather broad-brush for the sake of conciseness: It is convincingly explicated under which conditions neoliberalism could be established as economicpolitical concept in the mid-1970s.

Moreover, Crouch points out the aspects in which neoliberalism differs from competing positions. In contrast to classical liberalism neoliberalism does not consider competition an indispensible precondition for market processes. Instead, this position relies on the market with a view to the results: The guiding principle is not freedom of choice and consumer sovereignty, but the message is consumer orientation and greater welfare through greater efficiency. The result is the preferential treatment of large organisations instead of strong antitrust laws and therefore possibly also of global corporations which dominate the market instead of small and medium-sized enterprises. A central difference to the liberal representatives of a "social market economy" becomes particularly apparent with regard to social integration and the balance of interests: Neoliberals are avowed opponents of trade unions, as these prevent the smooth operation of the labour market. Furthermore neoliberalism opposes economic activities of the state, as this is said to protect specific industries or businesses 
from market competition. Conversely, the privatisation of state or public enterprises is advocated. Finally "new public management", i.e. the adaption of management instruments from the private sector to public service, is a central element of this field.

Crouch refers to the internal contradictions of the neoliberal trend, which he consistently infers from the market model and its specific limitations, i.e. he develops neoliberalism as a more or less persistent bundle of answers to specific disruptions of the market equilibrium, e.g. for dealing with externalities and public goods, transaction costs and distrust, market entry barriers or ties between industry and politics. Apart from favouring large corporations and scepticism towards the state as an economic actor and regulative factor, the plea for private instead of public financing is logically characteristic of neoliberalism. Private financing and hedging primary credit risks by introducing secondary venture markets has in several respects been an innovative and extremely successful idea. Risk diversification by secondary trade allowed not only for the integration of "big" money, but also smaller fortunes; it unburdened the state and promised - not only in Germany - possibly even additional profit opportunities via the involvement of state-owned banks.

During the boom banks then bundled heterogeneous risks into packages, where safe credits were brought together with unsecured mortgages and other uncertainties in dubious circumstances. When the bubble burst the system eventually slid into a new era of public debt, where the reappearance of the state as a regulatory power is not readily apparent.

Are there alternatives? Colin Crouch's answer is "possibly". Yet these cannot be found in a return to the "old" options, as meanwhile the struggle of state and market, which is the focus of the outlined positions of liberalism and social democracy, has become a three-way battle: The global corporation that dominates the market has entered the play as the third actor. Therefore it is not only market entry barriers that have to be regulated and new market exit risks that have to be controlled and financed by the state; the state is rather confronted with a global organisational power. Some states, particularly smaller ones, might not succeed in keeping this power under control. Crouch therefore counts on the international civil society as the new countervailing power, whose means for intervention arise on the basis of voluntary and anticipatory openness of companies in the context of corporate social responsibility and related concepts for stakeholder claims.

But should it be left to the executive boards of business enterprises to decide for which claims they take responsibility in terms of positive externalities? Certainly, undemocratic decisions can at times also be found in politics as Crouch notes. Perhaps Milton Friedman's thesis (1970), that companies have no other task than business and apart from that no right to pursue social aims as this cuts the principals' profits, was in Crouch's opinion naïve because Friedman underestimated lobbyism or - perhaps even deceitfully - omitted it, as I suspect. But Friedman's argument can also be viewed in a different way: The taxation of companies controls their actions and supplies parliaments with resources which they can, democratically legitimated, decide on the use of. The same holds true for the self-regulation of the economy which is brought into play by companies particularly when state regulation is lurking. Should market societies give up the right to distribute rights and obligations in the case of negative external- 
ities and the control of action? Ultimately Crouch argues that states in postdemocracy - here he builds on his previous works - are too weak to be able to enforce regulation in the struggle with multinationals.

Generally there can be no objections to the plea for the involvement of civil society in economy and politics, even if Crouch does not develop this intervention systematically in connection with an expansion of economic theories or an alternative political concept of liberalism. But the consistency of the argument demands that not only does a "new" political subject need to be identified in the left-wing tradition, but that at least its chances for change also need to be theoretically sounded out. Organisation theory might help to understand the behaviour of multinational concerns better. From this perspective it would become clearer that organisations control not only what counts in which context but moreover how they are controlled, if there were no occasional interference from uncertainties, counteracting strategies, unintended effects etc. (Duschek et al. 2012, p. 15). Involvement of civil society can certainly be a disruptive factor and an instrument that puts large organisations in irons - like the Liliputians did with Gulliver (Gröneweg \& Matiaske 2012). This analysis from organisation theory provides no reason for exuberant hope. The introduction of a secondary market for doing virtuous business between corporations and civil society remains a poor solution. Particularly in the continental European judicial area a functional equivalent of the binding state regulation of the market is sadly lacking.

In short: the systematic analysis of the rise of neoliberalism and the central argumentation of the emergence of multinational concerns stand opposite an all too optimistic argument with the introduction of a fourth actor into the triad - market, state and multinational corporation. Neglecting this criticism: a book well worth reading, particularly for scholars of business administration.

\section{References}

Duschek, S., Gaitanides, M., Matiaske, W., \& Ortmann, G. (2012). Macht, die aus Organisationen kommt. In S. Duschek, M. Gaitanides, W. Matiaske, \& G. Ortmann (eds.), Organisationen regeln: Die Wirkmacht korporativer Akteure (pp. 7-15). Wiesbaden: VS Verlag.

Friedman, M. (1970). The social responsibility of business is to increase its profits. New York Times Magazine, September 13.

Gröneweg, C., \& Matiaske, W. (2012). Gullivers Fesseln - Corporate Social Responsibility als Normbildungsprozess. In C. Jakobeit, R. Kappel, \& U. Mückenberger (eds.), Transnationale Akteure und Normbildungsnetzperke. Baden-Baden: Nomos (in print).

Hamburg, January 2012

Wenzel Matiaske*

Prof. Dr. Wenzel Matiaske, Helmut Schmidt University Hamburg, Institute for Human Resource Management and International Management and Research Professor at the German Institute for Economic Research (DIW), Berlin. E-mail: matiaske@hsu-hh.de. 